\title{
Swine influenza surveillance in East and Southeast Asia: a systematic review
}

\author{
Karen Trevennec ${ }^{1,2 *}$, Benjamin J. Cowling ${ }^{3}$, Marisa Peyre $^{1}$, Eugénie Baudon ${ }^{4}$, \\ Guy-Pierre Martineau ${ }^{2}$ and François Roger ${ }^{1}$ \\ ${ }^{1}$ French Agricultural Research Center for International Development (CIRAD), Animal and Integrated \\ Risk Management Research Unit (AGIRs), Montpellier, France, \\ ${ }^{2}$ Ecole National Vétérinaire de Toulouse (ENVT), INP, Toulouse, France, \\ ${ }^{3}$ University of Hong Kong, Hong Kong Special Administrative Region, People's Republic of China \\ and, \\ ${ }^{4}$ HKU-Pasteur Research Centre, Hong Kong Special Administrative Region, People's Republic of \\ China
}

Received 26 August 2011; Accepted 4 November 2011; First published online 29 November 2011

\begin{abstract}
East and Southeast Asia are important pig- and poultry-producing areas, where the majority of production takes place on small-scale farms with low biosecurity levels. This systematic review synthesizes data on swine influenza virology, serology and epidemiology in East and Southeast Asia. A total of 77 research articles, literature reviews and conference papers were selected and analyzed from 510 references retrieved from PubMed and ISI Web of Knowledge ${ }^{\mathrm{SM}}$. The number of published articles increased in the last 3 years, which may be attributed to improvement in monitoring and/or a better promotion of surveillance data. Nevertheless, large inequalities in surveillance and research among countries are underlined. Virological results represent the largest part of published data, while the serological and epidemiological features of swine influenza in East and Southeast Asia remain poorly described. The literature shows that there have been several emergences of swine influenza in the region, and also considerable evidence of multiple introductions of North American and avian-like European strains. Furthermore, several avian-origin strains are isolated from pigs, including $\mathrm{H} 5$ and $\mathrm{H} 9$ subtypes. However, their low seroprevalence in swine also shows that pigs remain poorly infected by these subtypes. We conclude that sero-epidemioligical investigations have been neglected, and that they may help to improve virological surveillance. Inter- and intracontinental surveillance of gene flows will benefit the region. Greater investment is needed in swine influenza surveillance, to improve our knowledge of circulating strains as well as the epidemiology and disease burden in the region.
\end{abstract}

Keywords: swine influenza, Southeast Asia, surveillance, cross-species transmission, emergence

\section{Introduction}

Pigs are the main animal reservoir of H1N1, H3N2 and $\mathrm{H} 1 \mathrm{~N} 2$ influenza viruses. $\mathrm{H} 1 \mathrm{~N} 1$ and $\mathrm{H} 3 \mathrm{~N} 2$ strains have emerged in swine on several occasions, consecutively,

*Corresponding author. E-mail: carlene.trevennec@cirad.fr with multiple cross-species transmissions from birds or humans (Brown, 2000; Webby and Webster, 2001). The first H1N2 viruses isolated were reassortants between H1N1 and H3N2 (Brown, 2000). These three subtypes (H1N1, H3N2 and H1N2) are spreading within swine populations worldwide with a continuous evolution (i.e. antigenic drift or reassortment), which increases the genetic diversity of swine influenza viruses (Webster et al., 1992; Brown, 2000; Vijaykrishna et al., 2011). 
Although the first three human influenza pandemics involved viruses of avian origin, the recent swine-origin H1N1 pandemic that emerged in 2009 (H1N1 pdm) convinced scientists that more attention needs to be paid to the pivotal role of pigs in the emergence of pandemic strains (Garten et al., 2009; Smith et al., 2009). Beyond their zoonotic potential and the pandemic risk, influenza viruses need to be monitored because of their sanitary and economic impact on the swine supply chain, since they are a major cause of pathology in swine in developing countries, and create a need for systematic vaccination of pigs (Olsen et al., 2006).

Due to lack of epidemiological, clinical and laboratory data on swine influenza, the scientific communities agree that surveillance activities urgently need to be improved around the world, including East and Southeast Asia (Smith et al., 2009; Van Reeth and Nicoll, 2009; OFFLU, 2011).

Countries in East and Southeast Asia include Brunei, Cambodia, China (including Hong-Kong Special Administrative Region (SAR) and Tä̈wan), Indonesia, Lao People's Democratic Republic (PDR), Malaysia, Myanmar, the Philippines, Thailand and Vietnam. According to statistics provided by the Food and Agriculture Organization (FAO) of the United Nations Organization, this region produced approximately 515 million pigs in 2008, representing more than half of the worldwide pig production. The pig production in East and Southeast Asia is characterized by a wide mixture of production types. A majority of producers are smallholders and are semicommercial, with their production aimed at home consumption and/or sale. Integrated production units are increasing in most developed countries within the region. The terms 'small-scale', 'medium-scale' and 'large-scale' do not have any precise definition (ACIAR, 2002). In the present review, we assume that a commercial system has more than 50 pigs per year reared in an industrial system, a backyard system has less than 50 pigs per year, and a semi-commercial system is a mixture between commercial and backyard (Liu et al., 2011). Backyard and semicommercial systems are characterized by a poor level of biosecurity and a mixture of species on a single farm, which could increase the risk of influenza virus persistence and emergence on swine farms (Olsen et al., 2006).

The aim of this report is to provide a systematic review of our current knowledge on swine influenza in East and Southeast Asia, in order to identify the needs in terms of surveillance in the region.

\section{Methods}

\section{Search strategy}

Swine influenza is not a World Organization for Animal Health (OIE) notifiable disease, except for influenza virus infections in pigs that fulfill the criteria of a new emerging disease (this was the case with pandemic H1N1/2009 up to September 2010). Therefore, no official reports or notification on country status regarding swine influenza are available. In November 2011, we searched the GenBank database to identify strains of swine influenza especially of $\mathrm{H} 1, \mathrm{H} 3, \mathrm{H} 5, \mathrm{H} 9$ and other subtypes reported in each country of interest. In parallel, we searched the PubMed database, using the following search strategy:

1. 'swine' OR 'pig*'

2. 'influenza' OR 'flu' OR 'H1*' OR 'H2*' OR 'H3*' OR 'H4*' OR 'H5*' OR ' $\mathrm{H} 7$ ') OR 'H9*'

3. 'China' OR 'Myanmar' OR 'Cambodia' OR 'Laos' OR 'Thailand' OR 'Vietnam' OR 'Brunei' OR 'Malaysia' OR 'Indonesia' OR 'Philippines' OR 'Hong Kong' OR 'Asia' 4. 1 AND 2 AND 3

In order to include proceedings papers, an additional search using the same strategy was performed with ISI Web of Knowledge ${ }^{\mathrm{SM}}$ to extract meeting documents that were unlisted in the MEDLINE ${ }^{\circledR}$ database. Finally, some unpublished data were also extracted from technical reports and steering committee reports on the OIE/FAO Network of Expertise on Animal Influenza website (http:// www.offlu.net/index.html). Although unpublished, this kind of information may be considered as expert opinions.

\section{Selection criteria}

Since the aim of the research on the GenBank database was to assess the relative distribution of circulating subtypes, all subtype strains were included, even when the genome was not fully sequenced. Phylogenetic analyses will not be presented. With regard to published articles, titles and then abstracts were reviewed using the following inclusion criteria: articles had to report primary virological or sero-epidemiological data on swine infections by the influenza virus in at least one country of interest. Experimental studies were excluded. Since the swine-origin H1N1 pdm may be called 'swine influenza' even in humans, the term 'veterinary science' was used to limit the search to animal health. The remaining articles reporting human infection were excluded. In the second step, the limit 'published in the last 10 years' was used to focus on the most recent references, which may highlight current needs in terms of data and surveillance.

\section{Data analysis}

For each reference, the publication date, the country and the main topic (i.e. virology, serology, both or epidemiology) were registered. For the most recent references, the source of data was categorized as monitoring (i.e. systematic sample collection on healthy animals, including surveillance programs), swine influenza outbreak investigation, cross-sectional survey, pooled data provided 


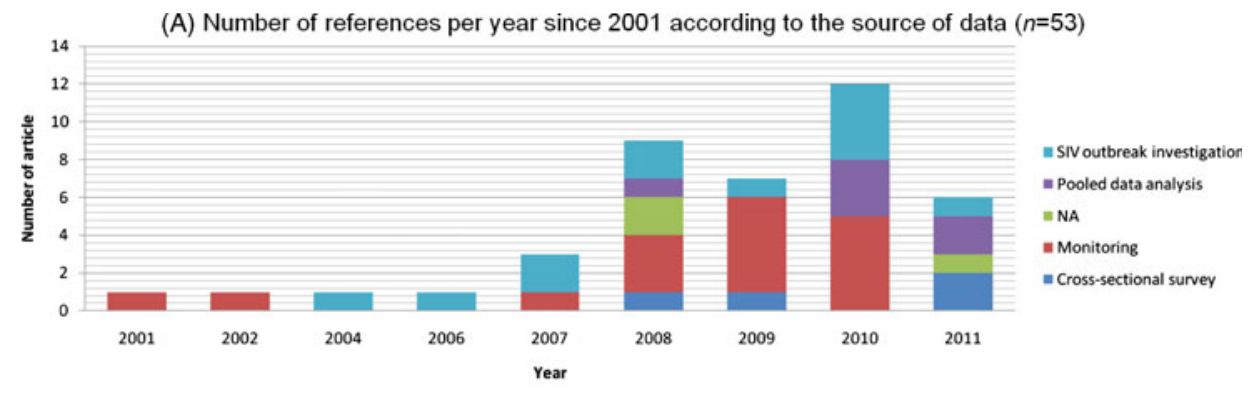

(B) Distribution of references per country ( $n=77)$

(C) Distribution of references per topic $(n=77)$
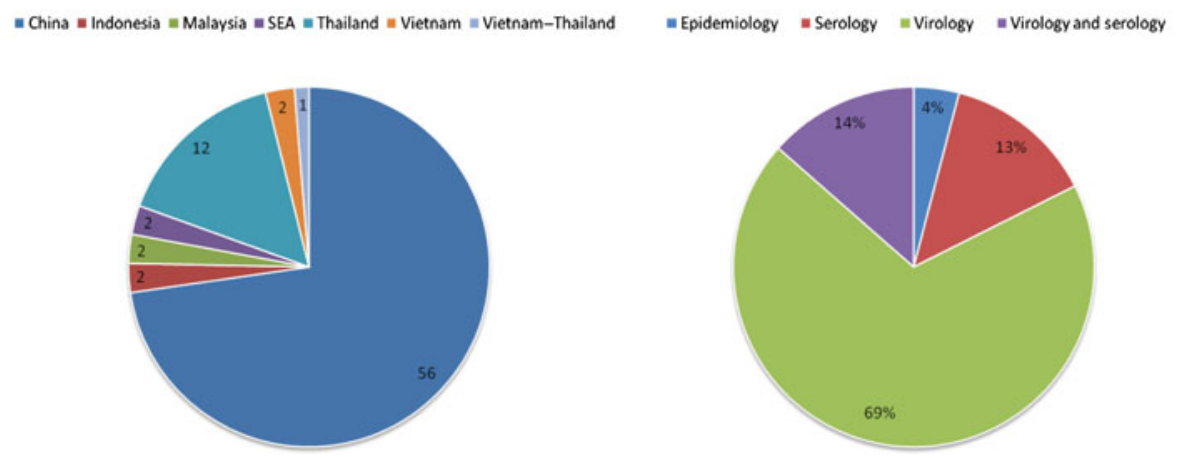

Fig. 1. References published on swine influenza in East and Southeast Asia in June 2011 retrieved on PubMed and ISI Web of Knowledge, according to the source of data (A), the country of origin of data (B) and the main topic (C).

by various databases, or not available. The following relevant variables were extracted from all selected articles and reports: the number of animals tested, the number of positive tests, the number of farms tested, the number of positive farms, laboratory assays including subtype testing, the time and the location (i.e. clinically affected farm, healthy farm, slaughterhouse and market) of sample collection, the age of the pigs and the farming system (i.e. backyard, semi-commercial and commercial), epidemiological context (i.e. details about neighboring farms), and season of epidemic peak and season of the lowest virus activity in the case of longitudinal studies. The isolation rate was computed for virological studies. The average value of isolation rates was also computed for each study design and compared using the Chi-squared test. The seroprevalence of each subtype was also reported. When $\mathrm{H} 1$ and $\mathrm{H} 3$ subtypes were both tested, the seroprevalence of influenza type A was estimated. Confidence intervals and relative precision were computed assuming an infinite population and dividing the standard deviation of each estimate by the estimate value.

\section{Results}

\section{Selected articles}

The initial PubMed research strategy retrieved 510 published articles, among which 286 were related to veterinary science. A total of 70 articles reporting virological or sero-epidemiological evidence of swine infection by an influenza virus in a country of interest were selected on the basis of their title and abstract. Two recent literature reviews on swine influenza in China were available (Yu et al., 2009; Liu et al., 2011). The additional search on ISI Web of Knowledge ${ }^{\mathrm{SM}}$ retrieved 52 articles of conference proceedings, among which seven matched the selection criteria. A total of 77 references ( 66 published in the last 10 years) were analyzed. A list of selected articles for the literature review from the PubMed database and conference proceedings provided by ISI Web of Knowledge is available with the authors.

As shown in Fig. 1A, the number of articles increased substantially in the last 3 years. Data were mainly provided by continuous monitoring and swine influenza outbreak investigations. The number of pooled data analyses increased in the last 2 years. The country from which most publishing originates is China, including Hong-Kong SAR and Tä̈wan, with a total of 56 published articles, followed by Thailand, with a total of 12 published articles (Fig. 1B). Virology is the most frequent topic of investigation. In comparison, serological and epidemiological studies represented only $10 \%$ and $4 \%$ of the references, respectively (Fig. 1C).

\section{Virology studies}

We identified four different study designs involving virus isolation. One approach consisted of systematic visits to slaughterhouses to collect samples in both healthy and formerly sick pigs. A second approach, also often related 
Table 1. Virological surveys on swine Influenza in East and Southeast Asia published in the last 10 years

\begin{tabular}{|c|c|c|c|c|c|c|}
\hline Type of study & Country & Isolation rate & Virus & Tested & Subtype & Reference \\
\hline \multirow{3}{*}{$\begin{array}{l}\text { Monitoring in } \\
\text { slaughterhouse }\end{array}$} & China & $1.69 \%$ & 84 & 4957 & $\mathrm{H} 9 \mathrm{~N} 2, \mathrm{H} 3 \mathrm{~N} 2$ & Peiris et al. (2001) \\
\hline & Thailand & $0.56 \%$ & 2 & 359 & $\mathrm{H} 3 \mathrm{~N} 2$ & Parchariyanon (2006) \\
\hline & Mean/total & $1.62 \%$ & 86 & 5316 & & \\
\hline \multirow[t]{10}{*}{$\begin{array}{l}\text { Monitoring in } \\
\text { healthy farms }\end{array}$} & Thailand & $0.56 \%$ & 2 & 359 & $\mathrm{H} 1 \mathrm{~N} 1, \mathrm{H} 1 \mathrm{~N} 2, \mathrm{H} 3 \mathrm{~N} 2$ & Thawatsupha \\
\hline & China & $0.44 \%$ & 9 & 2024 & $\mathrm{H} 1 \mathrm{~N} 1, \mathrm{H} 3 \mathrm{~N} 2$, other & Li et al. (2003) \\
\hline & China & $0.81 \%$ & 16 & 1985 & $\begin{array}{l}\mathrm{H} 1 \mathrm{~N} 1, \mathrm{H} 1 \mathrm{~N} 2, \mathrm{H} 3 \mathrm{~N} 2, \\
\mathrm{H} 5 \mathrm{~N} 1, \mathrm{H} 9 \mathrm{~N} 2\end{array}$ & Li et al. (2004) \\
\hline & China & $0.00 \%$ & 5 & 500 & $\mathrm{H} 1 \mathrm{~N} 1, \mathrm{H} 3 \mathrm{~N} 2$ & Yu et al. (2007) \\
\hline & Tä̈wan & $0.00 \%$ & 2 & 881 & $\mathrm{H} 1 \mathrm{~N} 2, \mathrm{H} 3 \mathrm{~N} 1$ & Shieh et al. (2008) \\
\hline & China & $0.52 \%$ & 10 & 1920 & $\mathrm{H} 1 \mathrm{~N} 1, \mathrm{H} 3 \mathrm{~N} 2, \mathrm{H} 3 \mathrm{~N} 8, \mathrm{H} 5 \mathrm{~N} 1$ & Tu et al. (2009) \\
\hline & China & $1.67 \%$ & 2 & 120 & $\mathrm{H} 1 \mathrm{~N} 2$ & Xu et al. (2009) \\
\hline & China & $0.82 \%$ & 29 & 3546 & $\mathrm{H} 1 \mathrm{~N} 1, \mathrm{H} 1 \mathrm{~N} 2, \mathrm{H} 3 \mathrm{~N} 2$ & Bi et al. (2010) \\
\hline & Thailand & $1.89 \%$ & 20 & 1061 & H1N1, H3N2, pH1N1 2009 & OFFLU (2011) \\
\hline & Mean/total & $0.77 \%$ & 95 & 12396 & & \\
\hline \multirow{10}{*}{$\begin{array}{l}\text { Swine influenza } \\
\text { outbreak investigation }\end{array}$} & China & $1.92 \%$ & 4 & 208 & H9N2 & Yu et al. (2008) \\
\hline & China & $4.16 \%$ & 15 & 361 & $\mathrm{H} 9 \mathrm{~N} 2$ & Cong et al. (2008) \\
\hline & Thailand & $2.83 \%$ & 3 & 106 & $\mathrm{H} 3 \mathrm{~N} 2$ & $\begin{array}{l}\text { Nakharuthai } \\
\text { et al. (2008) }\end{array}$ \\
\hline & China & $1.92 \%$ & 4 & 208 & $\mathrm{H} 9 \mathrm{~N} 2$ & Yu et al. (2008) \\
\hline & China & $0.46 \%$ & 3 & 650 & $\mathrm{H} 1 \mathrm{~N} 1, \mathrm{H} 1 \mathrm{~N} 2$ & Yu et al. (2009) \\
\hline & China & $100.00 \%$ & 3 & 3 & $\mathrm{H} 1 \mathrm{~N} 1$ & Qi et al. (2009) \\
\hline & Thailand & $5.83 \%$ & 7 & 120 & $\mathrm{H} 3 \mathrm{~N} 2$ & $\begin{array}{l}\text { Lekcharoensuk } \\
\text { et al. (2010) }\end{array}$ \\
\hline & Thailand & $10.00 \%$ & 2 & 20 & Pandemic H1N1/2009 & Sreta et al. (2010) \\
\hline & Vietnam & $0.90 \%$ & NA & NA & H1N1, H3N2, pH1N1 2009 & OFFLU (2011) \\
\hline & Mean/total & $2.45 \%$ & 41 & 1676 & & \\
\hline AIV outbreak investigation & Indonesia & $7.41 \%$ & 52 & 702 & $\mathrm{H} 5 \mathrm{~N} 1$ & Nidom et al. (2010) \\
\hline
\end{tabular}

NA, not available.

to national surveillance programs, consisted of single or repeated sample collection in randomly selected farms. Although selected farms usually had predominantly healthy pigs, some specimens were collected from sick animals. Nine other studies published in China and Thailand were based on the detection and reporting of outbreaks on pig farms, and on the viruses isolated from the sick animals. Finally, a single case study reported a high isolation rate of avian-origin SIV, obtained from an outbreak investigation of avian influenza virus (AIV), during outbreaks of H5N1 HPAI (highly pathogenic avian influenza) in poultry in Indonesia (Nidom et al., 2010). The average isolation rates according to each approach are presented in Table 1 . The isolation rate was significantly higher when samples were collected on clinically affected farms in comparison with other strategies $(P<0.05)$. Surprisingly, the highest isolation rate was obtained in the study that investigated commercial farms near previous $\mathrm{H} 5 \mathrm{~N} 1$ outbreaks in poultry farms in Indonesia.

As of November 2011, genomic data from a total of 710 strains have been published in the GenBank database by authors from Hong Kong SAR, 205 by authors from the People's Republic of China (21 by authors from Taiwan), 61 by authors from Thailand, 15 by authors from Indonesia, 6 by authors from Vietnam and 1 by authors from Malaysia. Several strains collected during surveillance activities have been sequenced in Hong-Kong SAR through research on H1N1 pdm (Smith et al., 2009; Vijaykrishna et al., 2011). The relative distribution of each subtype, on the basis of the hemagglutinin subtype, is presented in Fig. 2.

The first emergence of swine influenza in East and Southeast Asia was reported in 1969 in Taiwan during the Hong-Kong human epidemic involving H3N2 influenza virus (Kundin, 1970). The human-like H3N2 swine influenza virus spread within the Asian swine population along several reassortants, including human seasonal, classical swine and avian $\mathrm{H} 5$ viruses (Yu et al., 2007; Cong et al., 2010; Ngo et al., 2011). This subtype has been reported in Hong-Kong SAR (Vijaykrishna et al., 2011), in mainland China (Yu et al., 2007), in Taiwan (GenBank), in Thailand (Chutinimitkul et al., 2008; Takemae et al., 2008) and in Vietnam (Ngo et al., 2011). Surveillance results have led to contradictory conclusions, but this subtype may still be spreading in China (Bi et al., 2010; Vijaykrishna et al., 2011).

The H1N1 subtype was first isolated in 1991 (Kupradinun et al., 1991; Vijaykrishna et al., 2011). This classical swine virus lineage remained the predominant one since its emergence until 2002 (Vijaykrishna et al., 2011). This lineage or clustering reassortants have been reported in mainland China (Liu et al., 2011; Vijaykrishna et al., 2011), in Taiwan (Shieh et al., 2008) and in Thailand (Chutinimitkul et al., 2008; Takemae et al., 2008). 


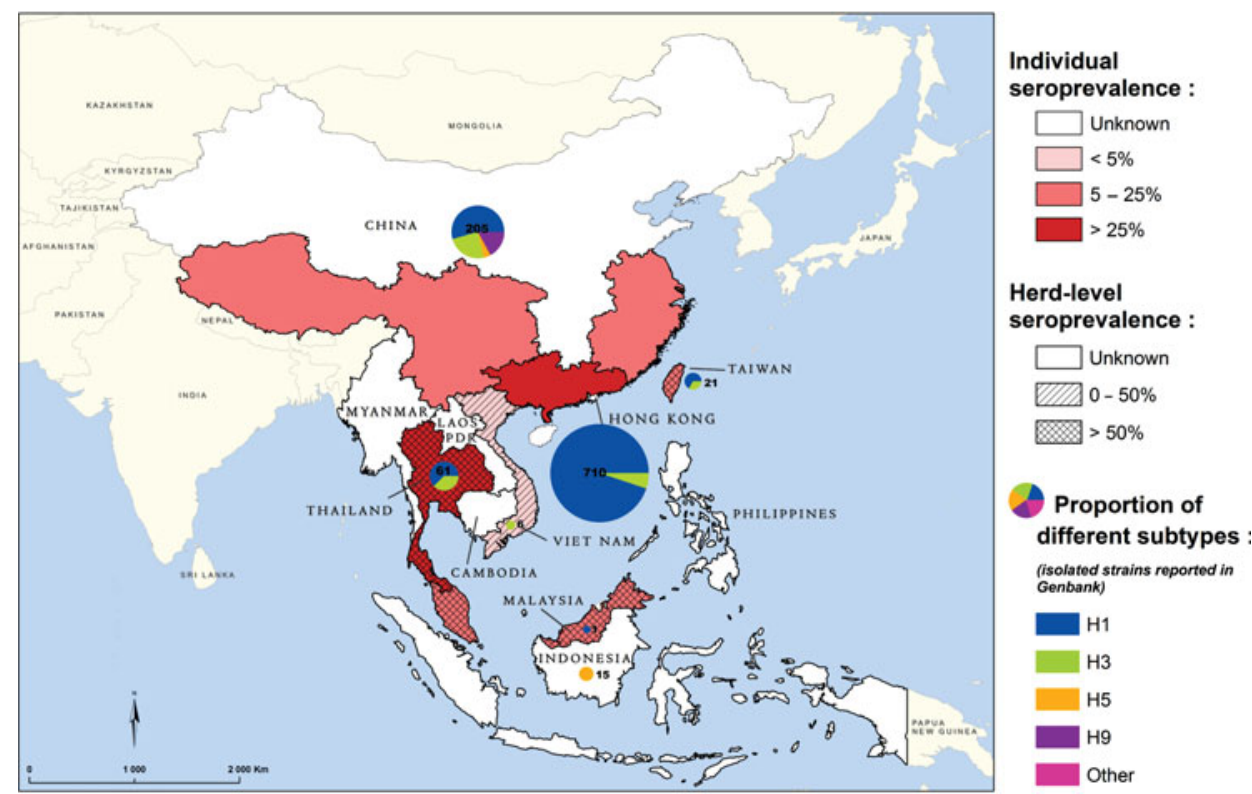

Fig. 2. Swine influenza in East and Southeast Asia. Isolated subtypes (GenBank), herd-level and individual seroprevalence of swine influenza type A last published in China (Liu et al., 2011), Taiwan (Shieh et al., 2008), Malaysia (Suriya et al., 2008), Thailand (Parchariyanon, 2006) and Vietnam (Trevennec et al., 2011).

The European avian-like H1N1 emerged in China in 1993 (Guan et al., 1996), long before the first report of the Eurasian avian-like H1N1, which emerged in 2001 and became the predominant H1 lineage since 2005 in China (Vijaykrishna et al., 2011) and Thailand (Takemae et al., 2008). The US origin H1N2 has been reported since 2002 and is still circulating in China (Xu et al., 2009; Bi et al., 2010; Vijaykrishna et al., 2011) and Thailand (Takemae et al., 2008). In 2009, the emergence of H1N1 pdm may be involved in some changes in the $\mathrm{H} 1$ distribution. This new virus has been isolated in China (Vijaykrishna et al., 2011) and Thailand (Sreta et al., 2010). This lineage is currently spreading in swine, and the first reassortants with a swine influenza virus have been identified in Hong-Kong SAR (Vijaykrishna et al., 2010).

Pig infections with $\mathrm{H} 5 \mathrm{~N} 1$ and $\mathrm{H} 9 \mathrm{~N} 2$ avian-origin viruses have only been reported in Asia. The HPAI H5N1 subtype has been isolated several times from Chinese (Zhu et al., 2008) and Indonesian pigs (Takano et al., 2009; Nidom et al., 2010), with evidence of pig-to-pig transmission of an HPAI $\mathrm{H} 5 \mathrm{~N} 1$ avian-origin virus in Indonesia (Nidom et al., 2010). The avian H9N2 subtype has been reported in China and Hong Kong SAR on several occasions (Peiris et al. 2001; Cong et al., 2008; Yu et al., 2008, 2011). Unusual subtypes have also been isolated sporadically, including the equine-origin $\mathrm{H} 3 \mathrm{~N} 8$ (Tu et al., 2009) and the avian-origin H6N6 (Zhang et al., 2011).

\section{Serological data}

Since a detailed review was performed in China in 2011 (Liu et al., 2011), we did not perform additional analysis for this country. The synthesis of seroprevalence studies at the individual level was thus computed on the basis of 9 references. The average seroprevalence of influenza type A could be extracted or computed on the basis of the literature review in China (Liu et al., 2011), three references in Thailand (Damrongwatanapokin et al., 2003; Parchariyanon, 2006; Kitikoon et al., 2011), one reference in Malaysia (Suriya et al., 2008) and one in Vietnam (Trevennec et al., 2011). As shown in Table 2, the seroprevalence of influenza A ranges from 3.1\% in semi-commercial pig farms in the spring in Vietnam (Trevennec et al., 2011) to an average of $61.4 \%$ in industrial pig farms in south China (Liu et al., 2011). Pigs from all age groups from two farms that were tested in Thailand in 2011 were found seropositive to swine influenza (Kitikoon et al., 2011).

The proportion of each subtype was provided from the pooled data analysis in China, in which $\mathrm{H} 1, \mathrm{H} 3, \mathrm{H} 5$, and H9 subtypes were tested (Liu et al., 2011), from studies in Thailand on H1N1 and H3N2 subtypes (two publications) (Damrongwatanapokin et al., 2003; Parchariyanon, 2006) and Malaysia (one publication), where H1N1 and H3N2 were tested (Suriya et al., 2008). The overall results indicate a higher proportion of $\mathrm{H} 1 \mathrm{~N} 1$ in comparison with other subtypes, which is consistent with the virus isolation data. There has been an increase in seroprevalence of H1N1 over the last 10 years in China (Liu et al., 2011), whereas the H3N2 seroprevalence has been decreasing (Song et al., 2010), except in Thailand, where it remains as the predominant subtype (OFFLU, 2011).

Although Asian pigs have been largely exposed to the HPAI H5N1 virus in the last 10 years, there is no serological evidence that the virus can spread significantly 
Table 2. Serological surveys on swine influenza in East and Southeast Asia in the last 10 years

\begin{tabular}{|c|c|c|c|c|c|c|c|c|c|c|}
\hline Country & Virus & Sample & $\begin{array}{l}\text { Proportion } \\
\text { positive } \\
(\%) \\
\end{array}$ & $\begin{array}{l}\text { Relative } \\
\text { precision } \\
(\%) \\
\end{array}$ & Age & $\begin{array}{l}\text { Farming } \\
\text { system }\end{array}$ & Time & $\begin{array}{l}\text { Influenza } \\
\text { context }\end{array}$ & Type of study & Reference \\
\hline \multirow[t]{6}{*}{ China } & Type A & 32311 & 20.24 & 0.04 & \multirow[t]{9}{*}{ All } & \multirow{9}{*}{$\begin{array}{c}\text { Commercial } \\
\text { (various } \\
\text { densities) }\end{array}$} & \multirow[t]{9}{*}{ Annual } & \multirow[t]{9}{*}{ NA } & \multirow[t]{9}{*}{ Pooled data analysis } & \multirow[t]{9}{*}{ Liu et al. (2011) } \\
\hline & & 11168 & 31.14 & 0.03 & & & & & & \\
\hline & & 10139 & 28.60 & 0.03 & & & & & & \\
\hline & H5 & 5945 & 1.30 & 0.17 & & & & & & \\
\hline & $\mathrm{H} 7$ & 1440 & 0.00 & & & & & & & \\
\hline & & 3619 & 2.38 & 0.13 & & & & & & \\
\hline East China & Type A & - & 16.78 & & & & & & & \\
\hline $\begin{array}{l}\text { South West } \\
\text { China }\end{array}$ & Type A & - & 19.9 & & & & & & & \\
\hline South China & Type A & - & 61.4 & & & & & & & \\
\hline \multirow[t]{7}{*}{ Thailand } & Type A & 85 & 100.00 & 0.00 & NA & Commercial & Annual & $\begin{array}{l}\text { Pig-to-human } \\
\text { transmission }\end{array}$ & $\begin{array}{l}\text { Investigation of human } \\
\text { influenza in } 2 \text { pig } \\
\text { farms }\end{array}$ & Kitikoon et al. (2011) \\
\hline & Type A & 553 & 28.57 & 0.03 & \multirow[t]{3}{*}{ Fattening } & \multirow[t]{3}{*}{ Commercial } & \multirow[t]{3}{*}{ May-October } & \multirow{3}{*}{$\begin{array}{l}\text { AIV outbreak in } \\
\text { poultry }\end{array}$} & \multirow{3}{*}{$\begin{array}{l}\text { AIV outbreak } \\
\text { investigation }\end{array}$} & \multirow[t]{3}{*}{ Parchariyanon (2006) } \\
\hline & H1N1 & 553 & 7.96 & 0.07 & & & & & & \\
\hline & $\mathrm{H} 3 \mathrm{~N} 2$ & 553 & 20.61 & 0.04 & & & & & & \\
\hline & Type A & 859 & 43.89 & 0.02 & & \multirow{3}{*}{$\begin{array}{l}\text { Commercial } \\
\text { (high density } \\
\text { area) }\end{array}$} & \multirow[t]{3}{*}{ Winter } & \multirow[t]{3}{*}{ NA } & \multirow[t]{3}{*}{ Cross-sectional study } & \multirow{3}{*}{$\begin{array}{l}\text { Damrongwatanapokin } \\
\text { et al. (2003) }\end{array}$} \\
\hline & H1N1 & 367 & 19.89 & 0.04 & Sow & & & & & \\
\hline & H1N1 & 136 & 80.88 & 0.01 & Fattening & & & & & \\
\hline \multirow[t]{3}{*}{ Malaysia } & Type A & 727 & 24.35 & 0.03 & \multirow[t]{3}{*}{ NA } & \multirow[t]{3}{*}{ Commercial } & \multirow[t]{3}{*}{ NA } & \multirow[t]{3}{*}{ NA } & \multirow[t]{3}{*}{ Cross-sectional study } & \multirow[t]{3}{*}{ Suriya et al. (2008) } \\
\hline & H1N1 & 727 & 12.24 & 0.05 & & & & & & \\
\hline & $\mathrm{H} 3 \mathrm{~N} 2$ & 727 & 12.10 & 0.05 & & & & & & \\
\hline \multirow[t]{2}{*}{ Indonesia } & $\mathrm{H} 5 \mathrm{~N} 1$ & 300 & 1.00 & 0.20 & NA & Commercial & November-March & $\begin{array}{l}\text { AIV outbreak in } \\
\text { poultry }\end{array}$ & Long-term surveillance & Nidom et al. (2010) \\
\hline & $\mathrm{H} 5 \mathrm{~N} 1$ & 344 & 0.00 & - & NA & Backyard & December & $\begin{array}{l}\text { AIV outbreak in } \\
\text { poultry }\end{array}$ & Cross-sectional study & Santhia et al. (2009) \\
\hline \multirow[t]{2}{*}{ Vietnam } & Type A & 609 & 3.12 & 0.11 & Fattening & Semi-commercial & April & $\begin{array}{l}\text { AIV serology in } \\
\text { poultry }\end{array}$ & Cross-sectional study & $\begin{array}{l}\text { Trevennec et al. } \\
\text { (2011) }\end{array}$ \\
\hline & $\mathrm{H} 5 \mathrm{~N} 1$ & 3175 & 0.25 & 0.39 & NA & Semi-commercial & September-June & $\begin{array}{l}\text { AIV outbreak in } \\
\text { poultry }\end{array}$ & Cross-sectional study & Choi et al. (2005) \\
\hline
\end{tabular}

NA, not available. 
within swine populations. Surveillance results over large samples indicate that H5N1 may spread at a very low level in swine populations in Vietnam and Thailand with a seroprevalence of $0.25 \%(n=3000)$ (Choi et al., 2005) and $1 \%(n=300)$ in Indonesia (Santhia et al., 2009; Nidom et al., 2010). Investigations on $\mathrm{H} 5 \mathrm{~N} 1$ AIV outbreaks in poultry did not detect systematic evidence of $\mathrm{H} 5 \mathrm{~N} 1$ infection in pigs (Parchariyanon, 2006; Santhia et al., 2009; Song et al., 2010; Trevennec et al., 2011).

The H4 subtype has been measured in only one study in China and its relative seroprevalence appears to be important with up to $15 \%$ of pigs positive (Ninomiya et al., 2002). The H9 subtype seroprevalence has been evaluated only in China and was found in less than $3 \%$ of tested animals (Song et al., 2010; Liu et al., 2011).

The herd-level seroprevalence of swine influenza type A was computed for three countries: $17.1 \%$ in Vietnam (Trevennec et al., 2011), 60\% in China (Tä̈wan) (Shieh et al., 2008) and 83\% in Malaysia (Suriya et al., 2008).

\section{Risk factors}

Variables extracted from selected references allowed us to identify some risk factors for swine influenza. Seroprevalence of swine influenza in East and Southeast Asia has an epidemic peak during the fall and the winter seasons (Li et al., 2003; Shieh et al., 2008) and decreases in the spring (Trevennec et al., 2011), which is similar to the seasonal pattern described in Europe or the USA (Olsen et al., 2006). However, in Northern countries, multiple studies have shown that the disease can be observed all year round due to the total confinement of animals in industrial production (Olsen et al., 2006). In East and Southeast Asia, since the majority of pigs are kept in open houses (Bastianelli et al., 2007), we assume that the seasonality is an important pattern of the disease. The seroprevalence of influenza A is also associated with high-level animal densities (Liu et al., 2011).

Farm-level risk factors of swine influenza have been poorly investigated. A study undertaken in Malaysia, identified farm size, purchase of pigs, presence of domestic pets and avian species on the farm site, and distance to the closest neighboring farm as major risk factors for swine influenza (Suriya et al., 2008). In Vietnam, high seroprevalence is associated with breeding farms that produce 20-40 pigs per year (Trevennec et al., 2011). Surprisingly, the presence of poultry on a farm was shown to decrease the risk of swine influenza infection. The authors suggest that instead of poultry, seropositive farms mainly have mammalian pets such as cats and dogs, which has already been found to increase the risk of swine infection by influenza viruses (Suriya et al., 2008). Poultry was also not associated with the risk of swine influenza in a longitudinal survey in Chinese smallholders (Shu et al., 1996), and in a cross-sectional survey in a semi-commercial system in Vietnam (Trevennec et al.,
2011). Specific studies have also been conducted in pig farms during avian influenza H5N1 outbreaks in poultry in Taiwan (Shieh et al., 2008), Thailand (Parchariyanon, 2006) and Indonesia (Nidom et al., 2010). Even though the AIV has been isolated from pigs, no increase in seroprevalence was observed in swine (Nidom et al., 2010). In the framework of the pandemic H1N1/2009 in pig farms, epidemiological investigations are ongoing but, to our knowledge, no results have been published to date (OFFLU, 2010).

\section{Discussion}

Data on swine influenza in East and Southeast Asia have been provided in greater quantity and quality over the last 3 years. This increase may be due to greater investment and improvement of surveillance networks on influenza viruses in domestic animals in some countries and a higher interest in swine in the scientific community. Both are direct consequences of the H5N1 HPAI crisis in 2005 and the recent emergence of H1N1 pdm in 2009. The latter may also be the reason for which the number of synthesis articles or reviews, such as pooled data analyses, has increased in 2009-2010. Nevertheless, published data are provided by a small number of countries, notably China and Thailand. The map of the region (Fig. 2) highlights the limited knowledge on viral circulation in the whole region, especially in the centrally located countries. There were no data on swine influenza in Cambodia, Myanmar and Lao PDR; although it is likely that these countries are as affected as their neighbors. Varying levels of economic development may partially explain this observation as this is linked to surveillance capacity.

There have been several emergences of swine influenza in the region, and also considerable evidence of multiple introductions of $\mathrm{H} 1$ North American reassortants and avian-like H1 European strains. Such intercontinental flows increase the risk of genetic reassortments between strains from different geographical origins. This idea is well illustrated by the genesis of H1N1 pdm (i.e. reassortment between North American triple reassortants and Eurasian Avian-like viruses), which probably occurred in Asia (Smith et al., 2009). Generally, the phylogenetic diversity of swine influenza virus is greater in Eurasia than in North America and both populations are becoming more diverse over time (Shi et al., 2010). East and Southeast Asia are considered to be the influenza 'epicentre', especially because of high animal densities, the mixing of animal species and low levels of biosecurity (Shortridge and Stuart-Harris, 1982). Indeed, such epidemiological context may favor viral spread and the local genetic diversity of influenza viruses. However, the globalization of the pig market, including live animal movements, may cause viral diffusion worldwide, suggesting that some general trends may be observed at 
various locations. The frequency of the Asian origin human-like H3N2 seems to have decreased not only in Southeast Asia but also in both America and Europe (Vincent et al., 2008; Kuntz-Simon and Madec, 2009). Because the Southeast Asian pork market is highly connected, inter- and intra-continental surveillance of gene flows will benefit the region.

Repeated interspecific transmissions of avian or human viruses in pigs are more frequently reported in Asia than in the other continents, which underline the importance of monitoring cross-species transmission of influenza viruses in this region. However, low seroprevalences of $\mathrm{H} 5$ and $\mathrm{H} 9$ subtypes in swine also show that despite their constant exposure to avian viruses, pigs remain poorly infected by these subtypes. This leads to the following question: are such avian influenza infections in pigs more likely to give rise to emerging strains if they are driven by repeated cross-species introductions or by low-level transmission of AIVs among pigs?

This literature review shows low isolation rates and underlines the requirement for large sample collections for virological surveillance. This may in part be related to the short shedding period, freezing and thawing of swabs, and also poor cold chain management as viral isolation could not be done in local laboratories. An option for increasing the isolation rate is to collect more samples from pigs on clinically affected farms. Unfortunately, no clear case definition of a suspect farm remains and swine infection may be asymptomatic. Furthermore, since the influenza virus is a major agent of porcine respiratory disease complex and may be associated with other pathogens, such as the porcine reproductive and respiratory syndrome virus (Nakharuthai et al., 2008; Yu et al., 2008), the influenza virus cannot be monitored as a unique pathogen and a global surveillance system of respiratory syndromes on pig farms is required. Such clinical surveillance requires heavy investments to set up an efficient surveillance network, the ability to report clinical cases on time, and the capacity to manage large sample collections from collection to analysis. Some countries will have fewer resources at their disposal than others, and may meet various barriers in the field.

Firstly, the effective participation of swine workers to report clinically affected animals may vary greatly with the industry sector, which is constituted in East and Southeast Asia of about $80 \%$ small-scale production systems and 20\% medium- to large-scale production systems (ACIAR, 2002; Cocks et al., 2009). In the small-scale and family production sector, pigs do not represent a major source of family income (ACIAR, 2002; Cocks et al., 2009). The lack of disease awareness and the lack of concern for biosecurity may be frequent and cause under-reporting. In the medium- to large-scale commercial sector, even though the awareness of swine workers is supposed to be higher (Cocks et al., 2009), there may be reluctance to report symptoms to the authorities, which may incur much heavier economic losses (weak or no compensation).
Secondly, the lack of reference laboratories with swine influenza expertise is well recognized in East and Southeast Asia (OFFLU, 2011), and virological assays, such as real-time PCR, virus isolation or sequencing are not available in all countries (Inui, 2009). Given these concerns, the clinical and virological surveillance programs of swine influenza and emerging influenza viruses in swine in East and Southeast Asia must include a capacity building component and the development of partnerships among laboratories for the sharing of expertise and eventually for organization of shipments.

In brief, virus isolation is essential to track gene flows, to improve diagnosis and to produce vaccines. However, in developing countries, where technical capacities and financial resources may be limited, we have identified three main critical points related to the development of an efficient surveillance network: the risk of under-reporting of clinical cases, the lack of laboratory capacity and difficulties in managing large numbers of samples, including collection, storage and analyses. Surveillance of swine influenza in the region needs to be based on simple, low-cost activities adapted to the context and capacities of each country.

Serologic surveillance is often thought of as having limited value because of the endemic status of swine influenza, as well as the use of vaccination in some countries. Thus, positive results are not specific to emergence and serological test interpretations are challenged by cross-reactivity. This explains why serological studies may be neglected in comparison with virological studies. Nevertheless, the large majority of pig farms in East and Southeast Asia are not vaccinated against influenza. We suggest that the serological tool may be exploited in East and Southeast Asia, because it offers the opportunity to perform large numbers of tests easily, rapidly and at relatively low cost.

A serious lack of knowledge about the disease determinants, including farming systems, commercial practices and environment was observed. Further studies need to be conducted to identify (i) the annual and seasonal fluctuations in seroprevalence, (ii) the relative proportions of circulating subtypes and (iii) at-risk populations. This information will help (i) to target the virological surveillance on at-risk time and location, (ii) to identify emerging subtypes using adapted serological testing and (iii) to plan sentinel surveillance based on serological profiles. Studies on these various surveillance options are ongoing and will be discussed after completion.

\section{Conclusion}

The published literature on swine influenza in East and Southeast Asia has improved our knowledge on virology in the last decade. Improvement in surveillance systems is essential to better track the virus in the entire region, in order to identify inter- and intra-continental gene flow. 
However, molecular analyses require high laboratory capacities and large sample collections. In East and Southeast Asia, surveillance networks are unequally efficient, depending on the country. Faced with limited resources, there is a need to develop modern and highly cost-effective alternative strategies. In a context of weak infrastructure and of a lack of laboratory capacity, serological data would help to improve surveillance activities by detecting some past and recent emergences. Further development of surveillance strategies, using sero-epidemiological data and other health indicators is under consideration.

\section{Acknowledgements}

This study was mainly funded by the French Ministry of Foreign Affairs (MAE) via the FSP project (GRIPAVI 2006-26) and the Lavoisier Program for scholarship. Special thanks to Marie Gély, from CIRAD for her support on mapping tools and Marisa Peyre, from CIRAD for assistance.

\section{References}

ACIAR (2002). Priorities for Pig Research in Southeast Asia and the Pacific to 2010. Canberra, Australia: Australian Centre for International Agricultural Research.

Bastianelli D, Derail L and Klotz S (2007). Traditional Pig Breeding. CIRAD. Available from http://pigtrop.cirad.fr/ content/view/full/1089/(accessed 4 November 2011).

Bi Y, Fu G, Chen J, Peng J, Sun Y, Wang J, Pu J, Zhang Y, Gao H, Ma G, Tian F, Brown IH and Liu J (2010). Novel swine influenza virus reassortants in pigs, China. Emerging Infectious Diseases 16: 1162-1164.

Brown IH (2000). The epidemiology and evolution of influenza viruses in pigs. Veterinary Microbiology 74: 29-46.

Choi YK, Nguyen TD, Ozaki H, Webby RJ, Puthavathana P, Buranathal C, Chaisingh A, Auewarakul P, Hanh NT, Ma SK, Hui PY, Guan Y, Peiris JS and Webster RG (2005). Studies of $\mathrm{H} 5 \mathrm{~N} 1$ influenza virus infection of pigs by using viruses isolated in Vietnam and Thailand in 2004. Journal of Virology 79: 10821-10825.

Chutinimitkul S, Thippamom N, Damrongwatanapokin S, Payungporn S, Thanawongnuwech R, Amonsin A, Boonsuk $\mathrm{P}$, Sreta D, Bunpong N, Tantilertcharoen R, Chamnanpood $\mathrm{P}$, Parchariyanon S, Theamboonlers A and Poovorawan $\mathrm{Y}$ (2008). Genetic characterization of H1N1, H1N2 and H3N2 swine influenza virus in Thailand. Archives of Virology 153: 1049-1056.

Cocks P, Abila R, Bouchot A, Benigno C, Morzaria S, Inthavong $\mathrm{P}$, Long NV, Bourgeois-Luthi N, Scoizet A and Sieng S (2009). Cross-Border movement and market chains of large ruminants and pigs in the Greater Mekong SubRegion, Bangkok. Available from http://ulm.animalhealthresearch. asia/newsletters/FAO_ADB_OIE_Cross-Border\%20movement \%20study_Final\%20Report.pdf (accessed 4 November 2011).

Cong Y, Wang G, Guan Z, Chang S, Zhang Q, Yang G, Wang W, Meng Q, Ren W, Wang C and Ding Z (2010). Reassortant between human-Like $\mathrm{H} 3 \mathrm{~N} 2$ and avian $\mathrm{H} 5$ subtype influenza A viruses in pigs: a potential public health risk. PLOS ONE 5: e12591.
Cong YL, Wang CF, Yan CM, Peng JS, Jiang ZL and Liu JH (2008). Swine infection with H9N2 influenza viruses in China in 2004. Virus Genes 36: 461-469.

Damrongwatanapokin S, Parchariyanon S and Pinyochon W (2003). Serological study of swine influenza virus H1N1 infection in pigs of Thailand. In: Fourth International Symposium on Emerging and Re-emerging Pig Diseases June 29-July 2, Rome. Available from http://www.unipr.it/ arpa/facvet/dip/dipsa/ric/prrs2003/262-262.pdf （accessed 4 November 2011).

Garten RJ, Davis CT, Russell CA, Shu B, Lindstrom S, Balish A, Sessions WM, Xu X, Skepner E, Deyde V, OkomoAdhiambo M, Gubareva L, Barnes J, Smith CB, Emery SL, Hillman MJ, Rivailler P, Smagala J, de Graaf M, Burke DF, Fouchier RA, Pappas C, Alpuche-Aranda CM, Lopez-Gatell H, Olivera H, Lopez I, Myers CA, Faix D, Blair PJ, Yu C, Keene KM, Dotson Jr PD, Boxrud D, Sambol AR, Abid SH, St George K, Bannerman T, Moore AL, Stringer DJ, Blevins P, Demmler-Harrison GJ, Ginsberg M, Kriner P, Waterman S, Smole S, Guevara HF, Belongia EA, Clark PA, Beatrice ST, Donis R, Katz J, Finelli L, Bridges CB, Shaw M, Jernigan DB, Uyeki TM, Smith DJ, Klimov AI and Cox NJ (2009). Antigenic and genetic characteristics of swine-origin 2009 $\mathrm{A}(\mathrm{H} 1 \mathrm{N1})$ influenza viruses circulating in humans. Science 325: 197-201.

Guan Y, Shortridge KF, Krauss S, Li PH, Kawaoka Y and Webster RG (1996). Emergence of avian H1N1 influenza viruses in pigs in China. Journal of Virology 70: 8041-8046.

Inui K (2009). South East Asia Sub-Regional Laboratory Network, Technical Meeting, ed. FAO, Bangkok, Thailand.

Kitikoon P, Sreta D, Tuanudom R, Amonsin A, Suradhat S, Oraveerakul K, Poovorawan $\mathrm{Y}$ and Thanawongnuwech $\mathrm{R}$ (2011). Serological evidence of pig-to-human influenza virus transmission on Thai swine farms. Veterinary Microbiology 148: 413-418.

Kundin WD (1970). Hong Kong A-2 influenza virus infection among swine during a human epidemic in Taiwan. Nature 228: 857 .

Kuntz-Simon G and Madec F (2009). Genetic and antigenic evolution of swine influenza viruses in Europe and evaluation of their zoonotic potential. Zoonoses and Public Health 56: 310-325.

Kupradinun S, Peanpijit P, Bhodhikosoom C, Yoshioka Y, Endo A and Nerome K (1991). The first isolation of swine H1N1 influenza viruses from pigs in Thailand. Archives of Virology 118: 289-297.

Lekcharoensuk P, Nanakorn J, Wajjwalku W, Webby R and Chumsing W (2010). First whole genome characterization of swine influenza virus subtype $\mathrm{H} 3 \mathrm{~N} 2$ in Thailand. Vet Microbiol 145(3-4): 230-244.

Li H, Xin X, Yang H, Li Y, Qin Y, Xuehui C, Chen H, Yu K, Bi Y and Tong $G$ (2003). Serological and virologic surveillance for swine influenza virus infections among pigs over large areas in China in 1998-2002, paper presented to the 4th International Symposium on Emerging and Reemerging Pig Diseases, Rome, June 29-July 2, 2003.

Li H, Yu K, Xin X, Yang H, Li Y, Qin Y, Bi Y, Tong G and Chen H (2004). Serological and virologic surveillance of swine influenza in China from 2000 to 2003. International Congress Series 1263: 754-757.

Liu W, Wei MT, Tong Y, Tang F, Zhang L, Fang L, Yang H and Cao WC (2011). Seroprevalence and genetic characteristics of five subtypes of influenza A viruses in the Chinese pig population: a pooled data analysis. Veterinary Journal 187: 200-206.

Nakharuthai C, Boonsoongnern A, Poolperm P, Wajjwalku W, Urairong K, Chumsing W, Lertwitcharasarakul $\mathrm{P}$ and Lekcharoensuk P (2008). Occurrence of swine influenza 
virus infection in swine with porcine respiratory disease complex. Southeast Asian Journal of Tropical Medicine and Public Health 39: 1045-1053.

Ngo LT, Hiromoto Y, Pham VP, Le HT, Nguyen HT, Le VT, Takemae $\mathrm{N}$ and Saito $\mathrm{T}$ (2011). Isolation of novel triple-reassortant swine $\mathrm{H} 3 \mathrm{~N} 2$ influenza viruses possessing the hemagglutinin and neuraminidase genes of a seasonal influenza virus in Vietnam in 2010. Influenza and Other Respiratory Viruses doi: 10.1111/j.1750-2659.2011.00267.x [Epublication ahead of print].

Nidom CA, Takano R, Yamada S, Sakai-Tagawa Y, Daulay S, Aswadi D, Suzuki T, Suzuki Y, Shinya K, Iwatsuki-Horimoto K, Muramoto Y and Kawaoka Y (2010). Influenza A (H5N1) viruses from pigs. Indonesia. Emerging Infectious Diseases 16: $1515-1523$.

Ninomiya A, Takada A, Okazaki K, Shortridge KF and Kida H (2002). Seroepidemiological evidence of avian H4, H5, and H9 influenza A virus transmission to pigs in southeastern China. Veterinary Microbiology 88: 107-114.

OFFLU (2010). Strategy Document for Surveillance and Monitoring of Influenzas in Animals. OIE-FAO Network of Expertise on Influenza. Available from http://www.offlu. net/(accessed 20 January 2010)

OFFLU (2011). Technical Meeting - Coordinating worldwide surveillance for influenza in pigs, OIE, FAO, Paris, France, 6-7 April 2011. Available at http://www.offlu.net/filead$\mathrm{min} /$ home/en/news/pdf/SIV-Summary_final.pdf (accessed 4 November 2011).

Olsen C, Brown I, Easterday B and Van Reeth K (2006). Swine influenza. Diseases of Swine. 9th edn. Ames, IA: Blackwell Publishing, pp. 469-482.

Parchariyanon S (2006). Investigation of influenza A virus infection in pigs from 5 reported AIV outbreak provinces in 2004. Journal of the Thai Veterinary Medical Association 57: 16-25.

Peiris JS, Guan Y, Markwell D, Ghose P, Webster RG and Shortridge KF (2001). Cocirculation of avian H9N2 and contemporary "human" H3N2 influenza A viruses in pigs in southeastern China: potential for genetic reassortment? Journal of Virology 75: 9679-9686.

Qi X, Pang B and Lu CP (2009). Genetic characterization of H1N1 swine influenza A viruses isolated in eastern China. Virus Genes 39(2): 193-199.

Santhia K, Ramy A, Jayaningsih P, Samaan G, Putra AA, Dibia N, Sulaimin C, Joni G, Leung CY, Sriyal J, Peiris M, Wandra T and Kandun N (2009). Avian influenza A H5N1 infections in Bali Province, Indonesia: a behavioral, virological and seroepidemiological study. Influenza and Other Respiratory Viruses 3: 81-89.

Shi W, Lei F, Zhu C, Sievers F and Higgins DG (2010). A complete analysis of HA and NA genes of influenza A viruses. PLOS ONE 5: e14454.

Shieh HK, Chang PC, Chen TH, Li KP and Chan $\mathrm{CH}$ (2008). Surveillance of avian and swine influenza in the swine population in Taiwan, 2004. Journal of Microbiology Immunology Infection 41: 231-42.

Shortridge K and Stuart-Harris C (1982). An influenza epicentre? Lancet 320: 812-813.

Shu LL, Zhou NN, Sharp GB, He SQ, Zhang TJ, Zou Ww and Webster RG (1996). An epidemiological study of influenza viruses among Chinese farm families with household ducks and pigs. Epidemiology and Infection 117: 179-188.

Smith GJ, Vijaykrishna D, Bahl J, Lycett SJ, Worobey M, Pybus OG, Ma SK, Cheung CL, Raghwani J, Bhatt S, Peiris JS, Guan Y and Rambaut A (2009). Origins and evolutionary genomics of the 2009 swine-origin H1N1 influenza A epidemic. Nature 459: 1122-1125.
Song XH, Xiao H, Huang Y, Fu G, Jiang B, Kitamura Y, Liu W, Liu D and Gao GF (2010). Serological surveillance of influenza A virus infection in swine populations in Fujian province, China: no evidence of naturally occurring H5N1 infection in pigs. Zoonoses and Public Health 57: 291-298.

Sreta D, Tantawet S, Na Ayudhya SN, Thontiravong A, Wongphatcharachai $M$, Lapkuntod $J$, Bunpapong $N$, Tuanudom R, Suradhat S, Vimolket L, Poovorawan Y, Thanawongnuwech R, Amonsin A and Kitikoon P (2010). Pandemic (H1N1) 2009 virus on commercial swine farm, Thailand. Emerg Infect Dis 16(10): 1587-1590.

Suriya R, Hassan L, Omar AR, Aini I, Tan CG, Lim YS and Kamaruddin MI (2008). Seroprevalence and risk factors for influenza a viruses in pigs in peninsular Malaysia. Zoonoses and Public Health 55: 342-351.

Takano R, Nidom CA, Kiso M, Muramoto Y, Yamada S, Shinya K, Sakai-Tagawa Y and Kawaoka Y (2009). A comparison of the pathogenicity of avian and swine H5N1 influenza viruses in Indonesia. Archives of Virology 154: 677-681.

Takemae N, Parchariyanon S, Damrongwatanapokin S, Uchida Y, Ruttanapumma R, Watanabe C, Yamaguchi S and Saito T (2008). Genetic diversity of swine influenza viruses isolated from pigs during 2000 to 2005 in Thailand. Influenza and Other Respiratory Viruses 2: 181-189.

Thawatsupha P, Waicharoen S, Maneewong P, Prasittikhet K, Chittaganapitch M and Sawanpanyalert P (2003). Isolation and identification of influenza virus strains circulating in Thailand in 2001. Southeast Asian J Trop Med Public Health 34(1): 94-97.

Trevennec K, Mortier F, Lyazrhi F, Huong HT, Chevalier V and Roger F (2011). Swine influenza in Vietnam: preliminary results of epidemiological studies. Influenza and Other Respiratory Viruses 5: 71-73.

Tu J, Zhou H, Jiang T, Li C, Zhang A, Guo X, Zou W, Chen H and Jin $M$ (2009). Isolation and molecular characterization of equine H3N8 influenza viruses from pigs in China. Archives of Virology 154: 887-890.

Van Reeth K and Nicoll A (2009). A human case of swine influenza virus infection in Europe-implications for human health and research. European Surveillance 14: 19124.

Vijaykrishna D, Poon LLM, Zhu HC, Ma SK, Li OTW, Cheung CL, Smith GJD, Peiris JSM and Guan Y (2010). Reassortment of pandemic H1N1/2009 influenza A Virus in swine. Science 328: 1529

Vijaykrishna D, Smith GJD, Pybus OG, Zhu H, Bhatt S, Poon LLM, Riley S, Bahl J, Ma SK and Cheung CL (2011). Long-term evolution and transmission dynamics of swine influenza A virus. Nature 473: 519-522.

Vincent AL, Ma W, Lager KM, Janke BH and Richt JA (2008). Swine influenza viruses a North American perspective. Advances in Virus Research 72: 127-154.

Webby RJ and Webster RG (2001). Emergence of influenza A viruses. Philosophical Transactions of the Royal Society London B: Biological Sciences 356: 1817-1828.

Webster RG, Bean WJ, Gorman OT, Chambers TM and Kawaoka Y (1992). Evolution and ecology of influenza A viruses. Microbiological Reviews 56: 152-179.

Xu C, Zhu Q, Yang H, Zhang X, Qiao C, Chen Y, Xin X and Chen H (2009). Two genotypes of H1N2 swine influenza viruses appeared among pigs in China. Journal of Clinical Virology 46: 192-195.

Yu H, Hua RH, Wei TC, Zhou YJ, Tian ZJ, Li GX, Liu TQ and Tong GZ (2008). Isolation and genetic characterization of avian origin H9N2 influenza viruses from pigs in China. Veterinary Microbiology 131: 82-92. 
Yu H, Zhang GH, Hua RH, Zhang Q, Liu TQ, Liao M and Tong GZ (2007). Isolation and genetic analysis of human origin H1N1 and H3N2 influenza viruses from pigs in China. Biochemical and Biophysical Research Communications 356: 91-96.

Yu H, Zhang PC, Zhou YJ, Li GX, Pan J, Yan LP, Shi XX, Liu HL and Tong GZ (2009). Isolation and genetic characterization of avian-like H1N1 and novel ressortant H1N2 influenza viruses from pigs in China. Biochemical and Biophysical Research Communications 386: 278-283.

Yu H, Zhou Y-J, Li G-X, Ma J-H, Yan L-P, Wang B, Yang F-R, Huang M \& Tong G-Z (2011). Genetic diversity of
H9N2 influenza viruses from pigs in China: a potential threat to human health? Veterinary Microbiology 149: 254-261.

Zhang G, Kong W, Qi W, Long LP, Cao Z, Huang L, Qi H, Cao N, Wang W, Zhao F, Ning Z, Liao M and Wan XF (2011). Identification of an H6N6 swine influenza virus in southern China. Infection, Genetics and Evolution 11: 1174-1177.

Zhu Q, Yang H, Chen W, Cao W, Zhong G, Jiao P, Deng G, Yu K, Yang C, Bu Z, Kawaoka Y and Chen H (2008). A naturally occurring deletion in its NS gene contributes to the attenuation of an $\mathrm{H} 5 \mathrm{~N} 1$ swine influenza virus in chickens. Journal of Virology 82: 220-228. 